\title{
Unusual rearrangements and cyclizations involving polycyclic indolic systems
}

\author{
Alamdar Ashnagar, ${ }^{\text {a }}$ Patrick D. Bailey, ${ }^{*}$ Philip J. Cochrane, ${ }^{1 \mathrm{~b}}$ Timothy J. Mills, and \\ Richard A. Price
}

School of Chemistry (Faraday Building), The University of Manchester, Sackville Street, Manchester, M60 1QD, UK

Email:pat.bailey@manchester.ac.uk

\begin{abstract}
During the course of experiments to explore and develop cyclization reactions of indolic systems, a number of unusual rearrangement reactions were discovered, and are reported in this paper. We describe routes to 4 -substituted (methylsufanylmethyl)indole derivatives, and a simple route to a cyclopropanone derivative of a tetrahydro- $\beta$-carboline.
\end{abstract}

Keywords: Indole, Sommelet-Hauser rearrangement, Pictet-Spengler reaction, cyclopropanone

\section{Introduction}

There are an enormous number of important indolic natural products, containing a plethora of fused ring systems, as exemplified below (Figure 1). Our interest has been in using tryptophan as the chiral starting material for the synthesis of such compounds, ${ }^{2}$ and in developing synthetic methods for accessing the polycyclic structures. ${ }^{3}$<smiles>CN1C[C@H](C(=O)O)C=C2c3cccc4[nH]cc(c34)C[C@H]21</smiles>

Lysergic Acid 1<smiles>C=CC1(C)N2C(=O)[C@@H]3CCCN3C(=O)[C@@H]2C[C@]12Nc1ccccc1O2</smiles>

Brevianamide E 2

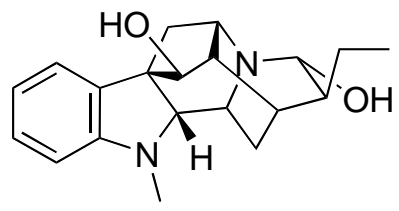

Ajmaline 3

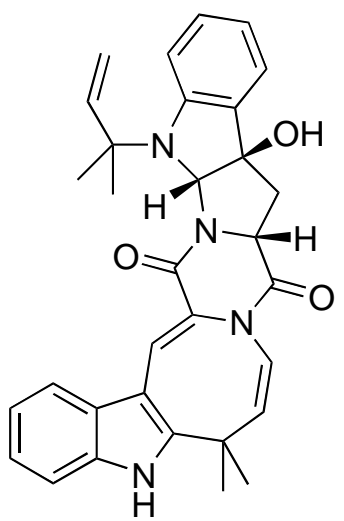

Okaramine A 4

\section{Figure 1}


We describe herein some of our cyclization studies, which have led to unusual and unexpected rearrangements. The first of these is a Sommelet-Hauser rearrangement, observed during the attempted ring-closure to the [6.5.5] fused system found in brevianamide E (2) and okaramine A (4); the second is a cyclopropanone forming reaction, observed whilst attempting the preparation of the spiro-system found in ajmaline (3).

\section{Results and Discussion}

\section{Section A. Methylsulfanylmethylation via Sommelet-Hauser rearrangements}

A key reaction in the synthesis of brevianamide E (2) and okaramine A (4) would be a difficult oxidative cyclization, in which the indolic 2-position becomes bonded to nitrogen. ${ }^{4} \mathrm{We}$ decided to explore this process using the model cyclization of brevianamide F (6) (Scheme 1, a), for which we were able to confirm that the use of $t$-butyl hypochlorite proceeds in only about $30 \%$ yield. $^{4 d}$ We had reasoned that treatment with Swern reagents ${ }^{5}$ ought to achieve the desired cyclization, and we explored the same model cyclization (Scheme 1, b). ${ }^{6}$ To our surprise, although the desired polycyclic skeleton was generated in 33\% yield using trifluoroacetic anhydride as the Swern electrophile, ${ }^{7}$ a methylsulfanylmethyl group was concurrently attached to the indole 4-position. Although unwanted for our work towards the brevianamides, accessing 4substituted tryptophans is difficult, and such compounds are of importance for QSAR studies of tryptophyl peptides, or for the synthesis of natural products such as lysergic acid (1); we therefore sought to explore the scope and limitations of this chemistry, as well as an understanding of the mechanism of the reaction.

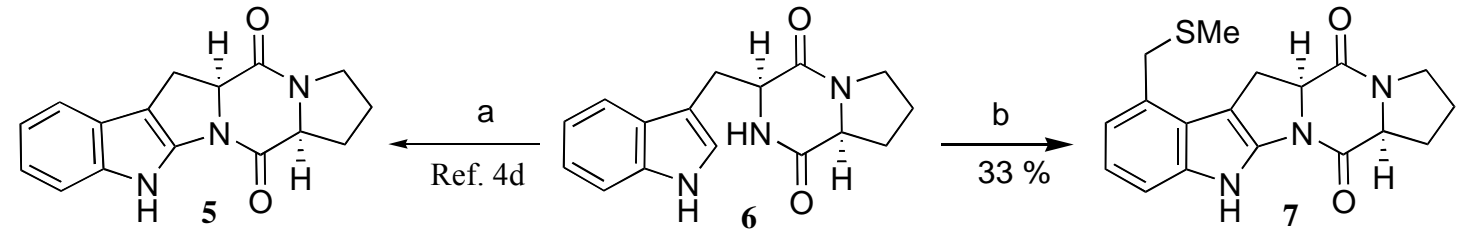

Scheme 1. Reagents and conditions: (a) $\mathrm{Bu}^{\mathrm{t} O C l}, \mathrm{NEt}_{3}, \mathrm{CH}_{2} \mathrm{Cl}_{2}, 0{ }^{\circ} \mathrm{C}$; (b) $\left(\mathrm{CF}_{3} \mathrm{CO}\right)_{2} \mathrm{O}$, DMSO, $\mathrm{CH}_{2} \mathrm{Cl}_{2},-78$ to 0 to $-78{ }^{\circ} \mathrm{C}$; add $\mathrm{NEt}_{3}$ and warm to $\mathrm{RT}$.

Our first set of indole analogues were simple acyl derivatives of tryptamine $\mathbf{8}$ and tryptophan methyl ester 9. We found that both of these reactions also proceeded with both cyclization and rearrangement, giving the 4-substituted products $\mathbf{1 0}$ and $\mathbf{1 1}$ in moderate yield, although the yield of the latter reaction was dramatically improved (to 95\%) when the reaction was carried out in acetonitrile. 


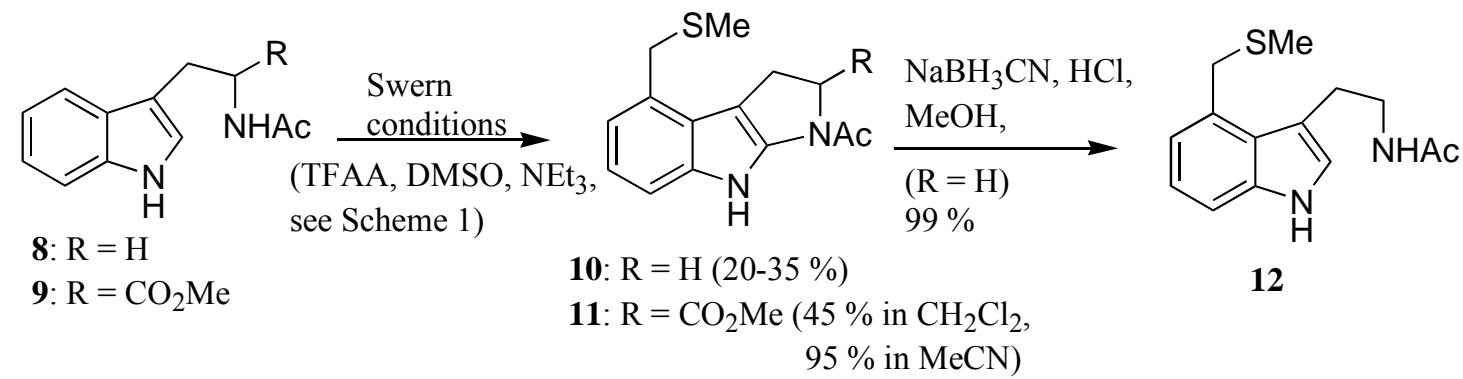

\section{Scheme 2}

The tryptophan derivative might be especially useful; for example, reduction with Raney nickel should generate the 4-methyltryptophan derivative, whilst other 4-substituted derivatives should be accessible using sulfide/sulfoxide chemistry, for incorporation into peptides. We were therefore pleased that reductive ring-opening of the tryptamine derivative $\mathbf{1 0}$ took place essentially quantitatively, thereby confirming that the ring-opening/unmasking can be easily achieved.

We next explored the range of indolic substrates suitable for the Sommelet-Hauser rearangement (Figure 2). Our choice was significantly guided by our proposed mechanism (see Scheme 3 below, and associated discussion), and we were therefore disappointed that only the three derivatives shown in Schemes 1 and 2 underwent the reaction.
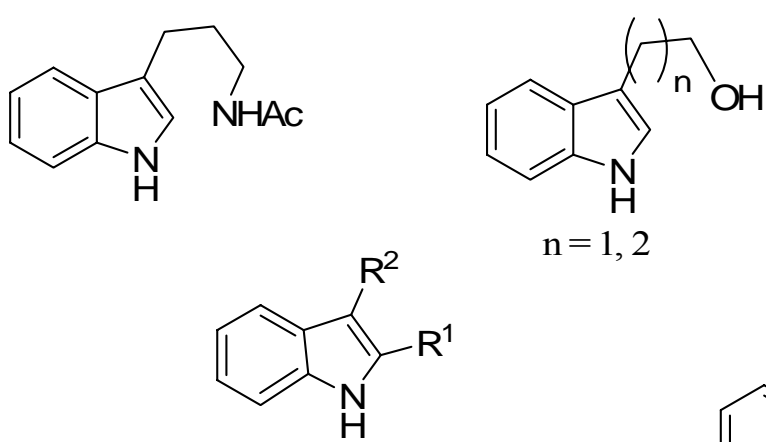

$$
\mathrm{n}=1,2
$$

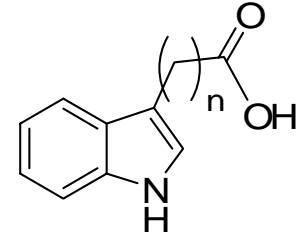

$\mathrm{n}=0,1,2$

$$
\begin{array}{ll}
\mathrm{R}^{1}=\mathrm{H}, \mathrm{R}^{2}=\mathrm{H} & \mathrm{R}^{1}=\mathrm{Me}, \mathrm{R}^{2}=\mathrm{Me} \\
\mathrm{R}^{1}=\mathrm{H}, \mathrm{R}^{2}=\mathrm{Me} & \mathrm{R}^{1}=\mathrm{H}, \mathrm{R}^{2}=\mathrm{CO}_{2} \mathrm{Me} \\
\mathrm{R}^{1}=\mathrm{Me}, \mathrm{R}^{2}=\mathrm{H} & \mathrm{R}^{1}=\mathrm{CO}_{2} \mathrm{Me}, \mathrm{R}^{2}=\mathrm{H}
\end{array}
$$

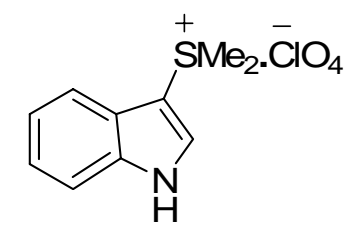

Figure 2. Substrates that failed to undergo the rearrangement.

Next we turned to the mechanism for this reaction, for which our proposal is shown in Scheme 3, in which a sulfonium intermediate is in equilibrium with an ylide, which can then undergo the Sommelet-Hauser rearrangement. ${ }^{8}$ 


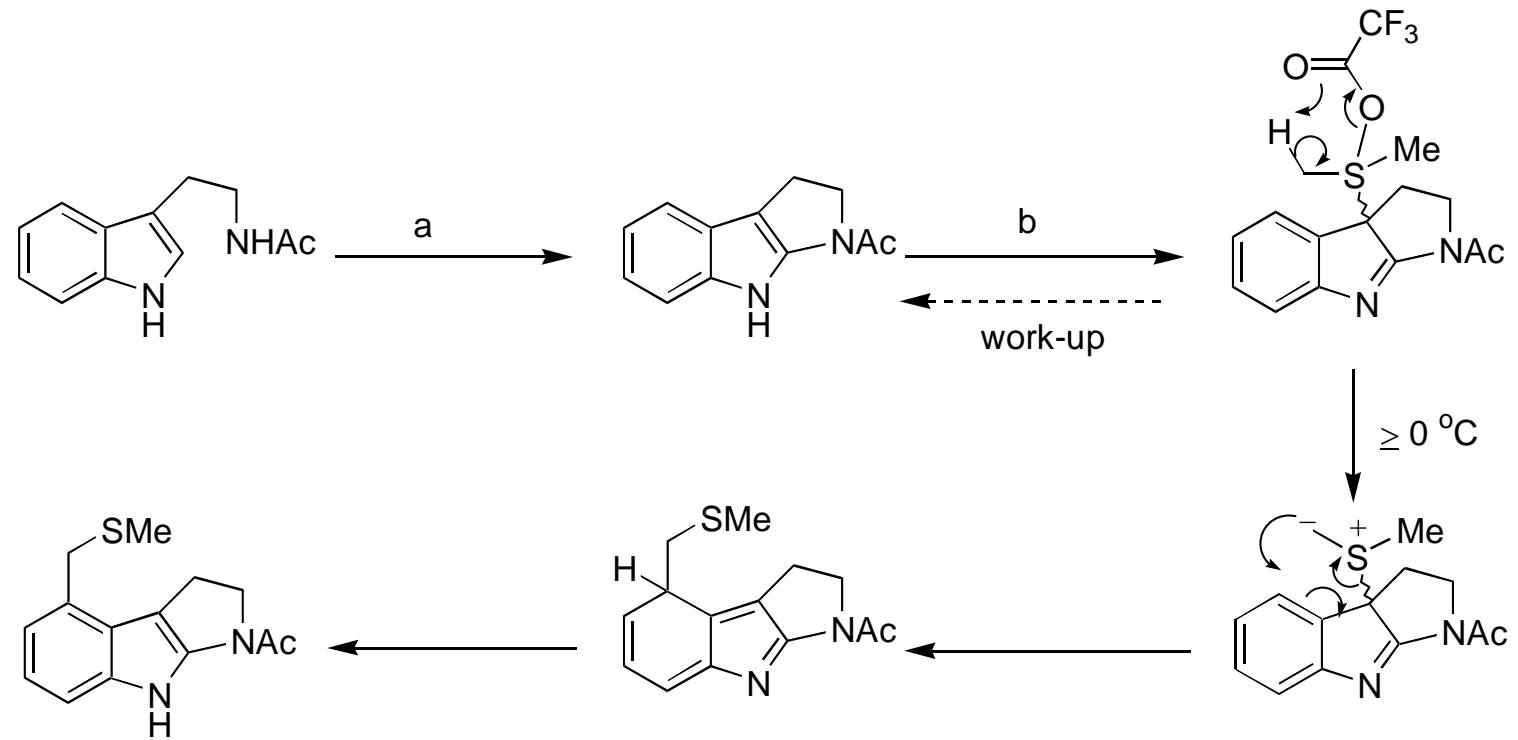

Scheme 3. Proposed mechanism for Swern oxidation (DMSO/TFAA then $\mathrm{ET}_{3} \mathrm{~N}$ ) (a) at low $\mathrm{T}$ or (b) with warming before basification.

When the reaction was carried out entirely at low temperature, then the expected cyclization took place without introduction of the $\mathrm{MeSCH}_{2}$ group; similarly, using only one equivalent of the Swern reagent, but allowing the reaction to warm up, also led to the simple cyclization product; finally, replacing trifluoroacetic anhydride with oxalyl chloride ${ }^{9}$ also led to cyclization without rearrangement.

These results indicate that the [6.5.5] system must be pre-formed before the SommeletHauser rearrangement can occur (in these systems, at least). Crucially, the Sommelet-Hauser rearrangement requires de-aromatization of the 'pyrrolic' indole ring before the [2,3] sigmatropic shift can occur, and it is noteworthy that the sulfonium salt (Figure 2, final entry) failed to undergo any reaction with triethylamine under our 'Swern' conditions. We had hoped that other heteroatoms tethered to the indole 3-position would be able to stabilise the key intermediates required for the Sommelet-Hauser rearrangement, but this turned out not to be the case. Although Swern et al have reported ortho- $\mathrm{CH}_{2} \mathrm{SMe}$ insertion in the oxidation of an aniline derivative, $^{7 \mathrm{~b}}$ our Swern-induced Sommelet-Hauser rearrangement for indolic systems has not been previously reported.

\section{Section B. Cyclopropanone formation from a diazomethyl ketone}

In work towards the [6.5.5.6] spiro system in ajmaline (3), we hoped to use a carbene insertion reaction, as outlined in Scheme 4.

We prepared the model diazoketone as shown in Scheme 5. Thus, allyl ester $14^{10}$ was benzylated, after which the trans specific Pictet-Spengler reaction ${ }^{11}$ gave the tetrahydro- $\beta$ carboline 15. After $\mathrm{N}^{\text {in }}$-methylation, and palladium catalyzed deprotection of the ester, the diazoketone 19 was prepared via the mixed anhydride 18. 


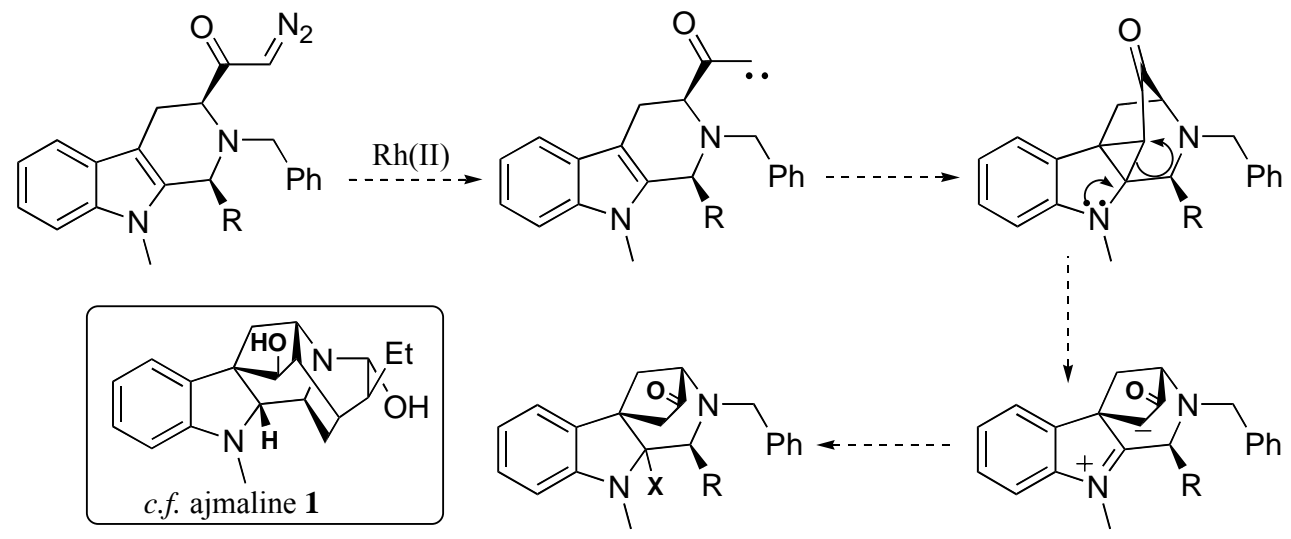

Scheme 4. Planned route to key [6.5.6.5] spiro ring system of ajmaline.

Intriguingly, reaction with rhodium II acetate generated the cyclopropanone 22 instead of the desired spiro system, as a single diastereoisomer, for which the IR stretch at $1805 \mathrm{~cm}^{-1}$ and ${ }^{13} \mathrm{C}$ peak at $205 \mathrm{ppm}$ were indicative of the strained ketone.

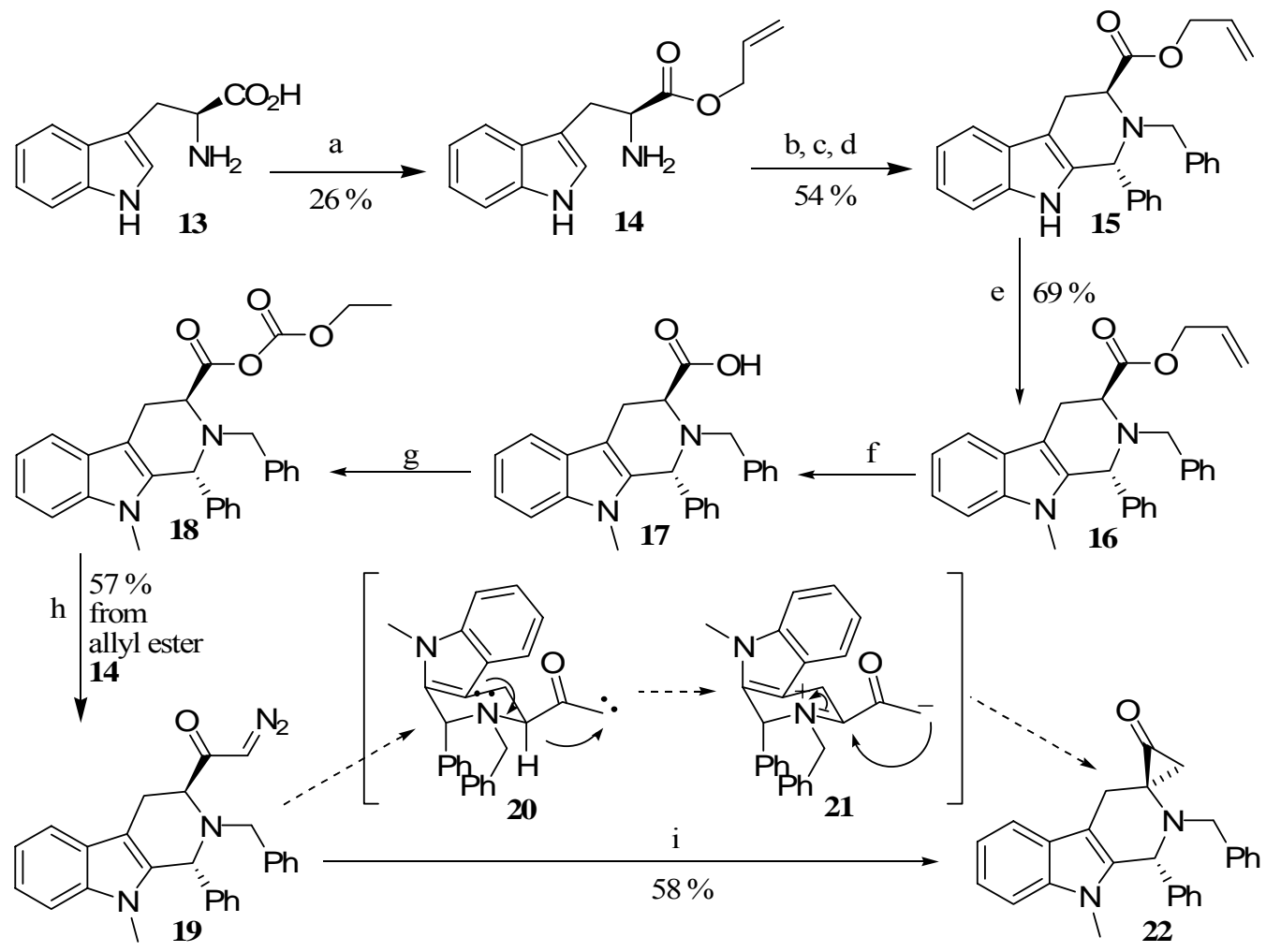

Scheme 5. Reagents and conditions; (a) allyl alcohol, $\mathrm{AcCl}$, reflux, $18 \mathrm{~h}$, (b) $\mathrm{PhCHO}, \mathrm{MeOH}, 2$ h, (c) $\mathrm{NaBH}_{4},-30{ }^{\circ} \mathrm{C}, 1 \mathrm{~h}$, (d) $\mathrm{PhCHO}, \mathrm{CHCl}_{3}$, reflux, $18 \mathrm{~h}$, (e) $\mathrm{NaH}, \mathrm{MeI}, \mathrm{DMF}, 0{ }^{\circ} \mathrm{C}$, (f) $\mathrm{Pd}\left(\mathrm{Ph}_{3}\right)_{4}, \mathrm{CH}_{2} \mathrm{Cl}_{2}$, morpholine, (g) ethyl chloroformate, $\mathrm{Et}_{3} \mathrm{~N}, \mathrm{CH}_{2} \mathrm{Cl}_{2},-10{ }^{\circ} \mathrm{C}, 1 \mathrm{~h}$, (h) $\mathrm{CH}_{2} \mathrm{~N}_{2}$, $\mathrm{Et}_{2} \mathrm{O}, \mathrm{DCM} 0{ }^{\circ} \mathrm{C}, 1 \mathrm{~h}, \mathrm{RT}, 72 \mathrm{~h}$, (i) $\mathrm{Rh}_{2}(\mathrm{OAc})_{4}, \mathrm{CH}_{2} \mathrm{Cl}_{2}, 18 \mathrm{~h}$, RT. 
If the mechanism we propose in Scheme 5 is correct, then the trans product shown would be expected, via pseudo-axial attack on the iminium intermediate in which the phenyl group is axial. $^{3 b}$ As in the case of the Sommelet-Hauser rearrangement, the fine interplay of steric and electronic factors are probably prerequisites for the rearrangement/cyclization, involving hydride shift and subsequent ring closure. We are exploring the generality of this unusual reaction, and the possible synthetic utility of the resulting cyclopropanones.

\section{Experimental Section}

General Procedures. General procedures followed during the course of the work detailed herein were similar to those reported elsewhere. ${ }^{2,3}$

\section{Synthetic studies}

\section{Section A}

Preparation of brevianamide F (6). ${ }^{4 \mathrm{~d}}$ L-Proline methyl ester hydrochloride (1.39 g: $\left.8.4 \mathrm{mmol}\right)$ was dissolved in DMF $(40 \mathrm{~mL})$ and diisopropylethylamine $(3 \mathrm{~mL})$. To a DMF $(60 \mathrm{~mL})$ solution of $N$-Z-tryptophan ( $2.84 \mathrm{~g}: 8.4 \mathrm{mmol})$ and 1-hydroxybenzotriazole $(1.25 \mathrm{~g}: 9.2 \mathrm{mmol})$ was added EDC (1.76 g: $9.2 \mathrm{mmol})$ in DMF $(100 \mathrm{~mL})$ at $0{ }^{\circ} \mathrm{C}$ over 5 minutes. This was stirred at $0{ }^{\circ} \mathrm{C}$ for 1 hour then at room temperature for half an hour. The DMF/DIPEA solution of L-proline was then added and the resultant solution stirred overnight. After this time the solvent was removed under vacuum and resultant oil dissolved in dichloromethane. This solution was washed with water ( 2 x $100 \mathrm{~mL})$, saturated sodium bicarbonate solution $(2 \times 100 \mathrm{~mL})$, citric acid solution $(0.7 \mathrm{M}: 2 \mathrm{x}$ $100 \mathrm{~mL}$ ) then water again before finally being dried over magnesium sulfate. The solution was filtered and the solvent removed under vacuum to give a crude white foam of the protected dipeptide Z-Trp-Pro-OMe (3.07 g: 80\%) which was used in the next step without further purification.

The dipeptide $(3.07 \mathrm{~g}: 6.8 \mathrm{mmol})$ was dissolved in methanol $(100 \mathrm{~mL})$ then the solvent removed under vacuum. This process was repeated twice before finally the starting material was dissolved in methanol $(150 \mathrm{~mL})$. To this solution was added palladium catalyst (Degussa type: $0.5 \mathrm{~g}$ ). The solution was flushed three times with hydrogen before being left to stir overnight under a hydrogen atmosphere. After this time, the catalyst was removed by filtration and the solvent removed in vacuo to give the crude product as a colourless oil. The crude material was purified by flash chromatography eluting with $1: 1$ ethyl acetate/dichloromethane to yield the desired product 6 as a white solid (1.77 g: 92\%): $\mathrm{R}_{\mathrm{f}} 0.13$ (1:99 methanol: dichloromethane); $v_{\max } / \mathrm{cm}^{-1}$ (KBr) 3288, 2923, 2872, 1674, 1653, 1429; $\delta_{\mathrm{H}}\left(200 \mathrm{MHz}, \mathrm{CDCl}_{3}\right)$ 1.79-2.04 (3H, m, Pro- $\left.\mathrm{CH}_{2}\right)$, 2.23-2.37 (1H, m, Pro- $\left.\mathrm{CH}_{2}\right), 2.92\left(1 \mathrm{H}, \mathrm{dd}, J 15.1,10.4 \mathrm{~Hz}\right.$, one of Trp- $\left.\mathrm{CH}_{2}\right), 3.55-3.72(3 \mathrm{H}, \mathrm{m}$, one of Trp- $\mathrm{CH}_{2}$ and Pro- $\left.\mathrm{CH}_{2}\right), 3.77(1 \mathrm{H}, \mathrm{dd}, J 3.7,0.7 \mathrm{~Hz}$, Pro- $\alpha-\mathrm{CH}), 4.30(1 \mathrm{H}, \mathrm{dd}, J 10.4,2.8$ 
Hz, Trp- $\alpha-\mathrm{CH}), 5.85(1 \mathrm{H}$, br s, NH), $7.04(1 \mathrm{H}, \mathrm{d}, J 2.2 \mathrm{~Hz}, \mathrm{CH}), 7.12$ (1H, ddd, J 7.7, 7.4, 1.2 $\mathrm{Hz}, \mathrm{CH}), 7.21$ (1H, ddd, J 7.7, 7.4, $1.5 \mathrm{~Hz}, \mathrm{CH}), 7.37(1 \mathrm{H}, \mathrm{dd}, J 7.7,1.5 \mathrm{~Hz}, \mathrm{CH}), 7.58(1 \mathrm{H}, \mathrm{dd}, J$ 7.4, $1.2 \mathrm{~Hz}, \mathrm{CH}), 8.62\left(1 \mathrm{H}\right.$, br s, NH); $\delta_{\mathrm{C}}\left(50 \mathrm{MHz}, \mathrm{CDCl}_{3}\right) 22.5\left(\mathrm{CH}_{2}\right), 26.7\left(\mathrm{CH}_{2}\right), 28.2\left(\mathrm{CH}_{2}\right)$, $45.3\left(\mathrm{CH}_{2}\right), 54.5(\mathrm{CH}), 59.1(\mathrm{CH}), 109.5(3-\mathrm{C}), 111.6(7-\mathrm{CH}), 118.4(6-\mathrm{CH}), 119.8(4-\mathrm{CH})$, $122.6(5-\mathrm{CH}), 123.4(2-\mathrm{CH}), 126.6(3 \mathrm{a}-\mathrm{C}), 136.6(7 \mathrm{a}-\mathrm{C}), 165.5(\mathrm{C}=\mathrm{O}), 169.3(\mathrm{C}=\mathrm{O})$; (Found: $\mathrm{C}$, 67.88 ; $\mathrm{H} .99 ; \mathrm{N}, 14.76 \% . \mathrm{C}_{16} \mathrm{H}_{17} \mathrm{~N}_{3} \mathrm{O}_{2}$ requires $\left.\mathrm{C}, 67.82 ; \mathrm{H}, 6.05 ; \mathrm{N}, 14.83 \%\right)$.

(5aS,13aS)-7-(Methylsulfanylmethyl)-1,2,3,6,11,13a-hexahydro-13H-pyrrolo[1",2":4',5']pyrazino[1',2':1,5]pyrrolo[2,3-b]indole-5(5aH),13-dione (7). To a solution of trifluoroacetic anhydride $(566 \mu \mathrm{L}: 4.0 \mathrm{mmol})$ in dichloromethane $(20 \mathrm{~mL})$ cooled to $-78{ }^{\circ} \mathrm{C}$ was added dimethylsulfoxide $(568 \mu \mathrm{L}: 8.0 \mathrm{mmol})$ in dichloromethane $(2 \mathrm{~mL})$. This solution was stirred at $78{ }^{\circ} \mathrm{C}$ for 10 minutes before a solution of brevianamide F $6(218.0 \mathrm{mg}$ : $0.77 \mathrm{mmol})$ was added in dichloromethane $(25 \mathrm{~mL})$ via a canula. The reaction was stirred at $-78{ }^{\circ} \mathrm{C}$ for 1 hour before triethylamine $(15 \mathrm{~mL})$ was added. The reaction was stirred for a further 2.5 hours during which time it was allowed to warm to room temperature. At this time the reaction mixture was poured into a separating funnel containing brine $(20 \mathrm{~mL})$. The organic phase was collected and washed further with sodium hydrogencarbonate solution $(2 \times 20 \mathrm{~mL})$ and brine $(2 \times 20 \mathrm{~mL})$ before being collected and dried over $\mathrm{CaCl}_{2}$. Upon filtration and removal of the solvent, the crude material was obtained as a yellow coloured foam. This was purified by flash chromatography eluting with 4:6 ethyl acetate and dichloromethane. The product 7 was isolated as a pale yellow coloured foam (72.1 mg: 33\%). $\mathrm{R}_{\mathrm{f}} 0.28$ (1:1 ethyl acetate:dichloromethane); m.p. 116-120 ${ }^{\circ} \mathrm{C} ; v_{\max } / \mathrm{cm}^{-1}$ (KBr) 3221, 2920, 1669, 1455, 1309, 1200, 747, 668; $\delta_{\mathrm{H}}\left(200 \mathrm{MHz}, \mathrm{CDCl}_{3}\right) 1.89\left(3 \mathrm{H}, \mathrm{s}, \mathrm{S}-\mathrm{CH}_{3}\right)$, 1.89-2.05 (2H, m, Pro- $\left.\mathrm{CH}_{2}\right)$, 2.13-2.41 (2H, m, Pro- $\left.\mathrm{CH}_{2}\right), 3.29$ (1H, dd, J 14.7, $10.1 \mathrm{~Hz}$, Trp$\left.\mathrm{CH}_{2}\right), 3.57\left(1 \mathrm{H}, \mathrm{dd}, J 14.7,7.7 \mathrm{~Hz}, \mathrm{Trp}-\mathrm{CH}_{2}\right), 3.54-3.62\left(2 \mathrm{H}, \mathrm{m}\right.$, Pro- $\left.\mathrm{CH}_{2}\right), 3.90\left(2 \mathrm{H}, \mathrm{s}, \mathrm{Ar}-\mathrm{CH}_{2}-\right.$ S), 4.23 (1H, dd, J 7.8, 7.5 Hz, Pro- CH), 5.12 (1H, dd, J 10.1, 7.7 Hz, Trp-CH), 6.92 (1H, d, J $7.7 \mathrm{~Hz}, \mathrm{CH}), 7.04(1 \mathrm{H}, \mathrm{t}, J 7.7 \mathrm{~Hz}, \mathrm{CH}), 7.32(1 \mathrm{H}, \mathrm{d}, J 7.7 \mathrm{~Hz}, \mathrm{CH}), 9.47\left(1 \mathrm{H}\right.$, br s, NH); $\delta_{\mathrm{C}}(50$ $\left.\mathrm{MHz}, \mathrm{CDCl}_{3}\right) 14.7\left(\mathrm{SCH}_{3}\right), 23.3\left(\mathrm{CH}_{2}\right), 26.3\left(\mathrm{CH}_{2}\right), 27.4\left(\mathrm{CH}_{2}\right), 34.9\left(\mathrm{CH}_{2}\right), 45.6\left(\mathrm{CH}_{2}\right), 59.9$ $(\mathrm{CH}), 66.8(\mathrm{CH}), 102.0$ (6a-C), $117.3(10-\mathrm{CH}), 120.3$ (9-CH), 121.1 (7-C), 121.9 (8-CH), 123.7 $(10 \mathrm{a}-\mathrm{C}) 135.8$ (6b-C), $139.3(10 \mathrm{a}-\mathrm{C}), 162.5(\mathrm{C}=\mathrm{O}), 165.3(\mathrm{C}=\mathrm{O}) ;$ HREI-MS m/z $\left(\mathrm{M}^{+}\right.$ $\left.\mathrm{C}_{18} \mathrm{H}_{19} \mathrm{~N}_{3} \mathrm{O}_{2} \mathrm{~S}\right)$ calc. 341.1198, obs. 341.1159.

Methyl (3S)-1-acetyl-4-(methylsulfanylmethyl)-1,2,3,8-tetrahydropyrrolo[2,3-b]indole-2carboxylate (11). To a solution of trifluoroacetic anhydride $(283 \mu \mathrm{L}: 2.0 \mathrm{mmol})$ in dichloromethane $(10 \mathrm{~mL})$ cooled to $-78^{\circ} \mathrm{C}$ was added dimethylsulfoxide $(284 \mu \mathrm{L}: 4.0 \mathrm{mmol})$ in dichloromethane $(2 \mathrm{~mL})$. This solution was stirred at $-78^{\circ} \mathrm{C}$ for 10 minutes before a solution of $\mathrm{N}$-acetyl tryptophan methyl ester $(99.7 \mathrm{mg}: 0.39 \mathrm{mmol})$ was added in dichloromethane $(15 \mathrm{~mL})$ via a canula. The reaction was stirred for 0.5 hours at $-78{ }^{\circ} \mathrm{C}$ before allowing the solution to warm to $0^{\circ} \mathrm{C}$ over 2 hours. The reaction was then cooled back to $-78{ }^{\circ} \mathrm{C}$ before triethylamine $(7$ $\mathrm{mL}$ ) was added. The reaction was stirred for a further 2.5 hours during which time it was allowed to warm to room temperature. At this time the reaction mixture was poured into a separating funnel containing brine $(20 \mathrm{~mL})$. The organic phase was collected and washed further with 
sodium hydrogencarbonate solution $(2 \times 20 \mathrm{~mL})$ and brine $(2 \times 20 \mathrm{~mL})$ before being collected and dried over $\mathrm{CaCl}_{2}$. Upon filtration and removal of the solvent, the crude material was obtained as a yellow foam. This was purified by flash chromatography eluting with 4:6 ethyl acetate/ dichloromethane, and the product $\mathbf{1 1}$ was isolated as a pale yellow coloured foam (55.7 mg: $45 \%$ ). Running the reaction on a $500 \mathrm{mg}$ scale of Ac-Trp-OMe, but replacing dichloromethane by acetonitrile, gave $580 \mathrm{mg}(95 \%)$ of the same product. $\mathrm{R}_{\mathrm{f}} 0.69$ (1:1 ethyl acetate:dichloromethane): $v_{\max } / \mathrm{cm}^{-1} 3200,2931,1675,1458,1315,1191 ; \delta_{\mathrm{H}}\left(100 \mathrm{MHz}, \mathrm{CDCl}_{3}\right)$ $1.94\left(3 \mathrm{H}, \mathrm{s}, \mathrm{CH}_{3}\right), 2.13\left(3 \mathrm{H}, \mathrm{s}, \mathrm{CH}_{3}\right), 3.31\left(1 \mathrm{H}, \mathrm{dd}, J 14.5,3.1 \mathrm{~Hz}, \mathrm{CH}_{2}\right), 3.67(1 \mathrm{H}, \mathrm{dd}, J$ 14.5, $\left.10.2 \mathrm{~Hz}, \mathrm{CH}_{2}\right), 3.83\left(3 \mathrm{H}, \mathrm{s}, \mathrm{CH}_{3}\right), 3.91\left(2 \mathrm{H}, \mathrm{s}, \mathrm{Ar}-\mathrm{CH}_{2}\right), 5.23(1 \mathrm{H}, \mathrm{dd}, J 10.2,3.1 \mathrm{~Hz}, \mathrm{CH}), 6.96$ $(1 \mathrm{H}, \mathrm{d}, J 7.6 \mathrm{~Hz}, \mathrm{CH}), 7.06(1 \mathrm{H}, \mathrm{dd}, J 7.6,7.4 \mathrm{~Hz}, \mathrm{CH}), 7.26(1 \mathrm{H}, \mathrm{d}, J 7.4 \mathrm{~Hz}, \mathrm{CH}), 9.00(1 \mathrm{H}$, br s, NH). $\quad \delta_{\mathrm{C}}\left(400 \mathrm{MHz}, \mathrm{CDCl}_{3}\right) 15.3(\mathrm{q}), 22.2(\mathrm{q}), 30.5$ (t), 35.5 (t), 53.5 (q), 66.7 (d), $99.0(\mathrm{~s})$, 117.1 (d), 120.7 (d), 121.4 (s), 121.8 (d), 123.9 (s), 135.9 (s), 143.4 (s), 167.6 (s), 171.7 (s).

Preparation of 4-(methylsulfanylmethyl)tryptamine (12). To a stirred suspension of 11 (21 $\mathrm{mg}, 80.3 \mathrm{mmol})$ in $\mathrm{MeOH}(5 \mathrm{ml})$ under nitrogen was added solid $\mathrm{NaBH}_{3} \mathrm{CN}(6 \mathrm{mg}, 0.1 \mathrm{mmol})$ followed by 2-3 drops of dilute $2 \mathrm{M} \mathrm{HCl}$. The solid rapidly dissolved to form a yellow solution. The reaction was followed by TLC and after $1 \mathrm{~h}$ the reaction mixture was evaporated to dryness. The residue was taken back up into dichloromethane, washed with saturated $\mathrm{NaHCO}_{3}(2 \mathrm{x})$, brine, dried $\left(\mathrm{MgSO}_{4}\right)$ and evaporated to dryness to afford $22 \mathrm{mg}(99 \%)$ of the reduction product 12 as a clear oil. $v_{\max } / \mathrm{cm}^{-1}$ (neat) 3401,3285 (br), 2970, 2912, 2854, 1658; $\delta_{\mathrm{H}}(400 \mathrm{MHz}$, $\left.\mathrm{CDCl}_{3}\right) 1.98(3 \mathrm{H}, \mathrm{s}), 2.14(3 \mathrm{H}, \mathrm{s}), 3.30(2 \mathrm{H}, \mathrm{t}, \mathrm{J} 7 \mathrm{~Hz}), 3.68(2 \mathrm{H}, \mathrm{q}, \mathrm{J} 7 \mathrm{~Hz}), 3.82$ (2H, s), 5.24 $(1 \mathrm{H}, \mathrm{s}, \mathrm{br}), 6.95(1 \mathrm{H}, \mathrm{d}, \mathrm{J} 7 \mathrm{~Hz}), 7.03(2 \mathrm{H}, \mathrm{m}), 7.26(1 \mathrm{H}, \mathrm{d}, \mathrm{J} 7 \mathrm{~Hz}), 9.56(1 \mathrm{H}, \mathrm{s}) ; \delta_{\mathrm{C}}(400 \mathrm{MHz}$, $\left.\mathrm{CDCl}_{3}\right) 15.2$ (q), 23.7 (q), 25.7 (t), 35.6 (t), 40.3 (t), 113.5 (s), 118.5 (d), 119.5 (d), 120.7 (s), 122.6 (d), 123.5 (d), 128.3 (s), 135.5 (s), 170.8 (s); HRMS (ES $\left.{ }^{+}\right) \mathrm{m} / \mathrm{z}\left(\mathrm{M}+\mathrm{Na}^{+} \mathrm{C}_{14} \mathrm{H}_{18} \mathrm{~N}_{2} \mathrm{ONaS}\right)$ calc. 285.1038 , obs. 285.1031 .

\section{Section B}

\section{L-Tryptophan allyl ester (14)}

To L-tryptophan $(15 \mathrm{~g}, 61 \mathrm{mmol})$ dissolved in allyl alcohol $(150 \mathrm{ml})$, acetyl chloride was then added, and the resulting purple solution was maintained at reflux for $18 \mathrm{hr}$. It was then cooled to RT, and $10 \%$ ammonia solution $(250 \mathrm{ml})$ and $\mathrm{CH}_{2} \mathrm{Cl}_{2}(150 \mathrm{ml})$ were added. The phases were separated and the aqueous extracted with $\mathrm{CH}_{2} \mathrm{Cl}_{2}(2 \times 250 \mathrm{ml})$. The combined organics were dried over $\mathrm{MgSO}_{4}$, filtered and solvent removed in vacuo. The product was purified by column chromatography using 50:50 $\mathrm{CHC1}_{3}$ : diethyl ether, giving $6.02 \mathrm{~g}(26 \%)$ of the white solid 14, which exhibited spectra in accordance with those already reported. ${ }^{10}$

Allyl (1R,3S)-1-phenyl-2-(phenylmethyl)-2,3,4,9-tetrahydro-1H-pyrido[3,4-b]indole-3carboxylate (15). L-Tryptophan allyl ester (1.0 g, $4.1 \mathrm{mmol})$ was dissolved in dry methanol (15 $\mathrm{ml})$, benzaldehyde (460 $\mu \mathrm{l}, 4.5 \mathrm{mmol})$ was then added and the resultant solution was stirred at 
RT for $2 \mathrm{hr}$. The solution was then cooled to $-30{ }^{\circ} \mathrm{C}$ and sodium borohydride $(77 \mathrm{mg}, 2.1 \mathrm{mmol})$ was added portion-wise over $5 \mathrm{~min}$. whilst maintaining the temperature at $-30^{\circ} \mathrm{C}$. The resultant mixture was then stirred at $-30{ }^{\circ} \mathrm{C}$ for $30 \mathrm{~min}$, warmed to $-10^{\circ} \mathrm{C}, \mathrm{AcOH}(400 \mu \mathrm{l})$ was then added and the reaction mixture was warmed to RT. The solvent was removed in vacuo, the residue redissolved in $\mathrm{CH}_{2} \mathrm{Cl}_{2}(15 \mathrm{ml})$ and benzaldehyde $(460 \mu \mathrm{l}, 4.5 \mathrm{mmol})$ added. The resultant solution was then heated to reflux for $18 \mathrm{hr}$, cooled to RT and the solvent removed in vacuo. The product 15 was purified by column chromatography 3:2 $\mathrm{CH}_{2} \mathrm{Cl}_{2}$ : hexane, to give $904 \mathrm{mg}(54 \%)$ of a colourless oil: $v_{\max } / \mathrm{cm}^{-1}$ (neat) $3405,3084,3060,3027,2945,2918,2851,1728,1600,1493$, 1454, 1371, 1357, 1323, 1302, 1270, 1217, 1178, 1140, 1091, 1075, 1028, 1010, 971, 926, 747, $700 ; \delta_{\mathrm{H}}\left(400 \mathrm{MHz}, \mathrm{CDCl}_{3}\right) 7.42-7.10(14 \mathrm{H}, \mathrm{m}), 5.87(1 \mathrm{H}, \mathrm{ddt}, J 17.2,10.5,5.5 \mathrm{~Hz}), 5.52(1 \mathrm{H}, \mathrm{s})$, $5.23(1 \mathrm{H}, \mathrm{dq}, J 17.2,1.5 \mathrm{~Hz}), 5.18$ (1H, dq, $J 10.5,1.5 \mathrm{~Hz}), 4.63$ (1H, ddt, $J$ 13.5, 5.5, $1.5 \mathrm{~Hz}$ ), $4.54(1 \mathrm{H}$, ddt, J 13.5, 5.5, $1.5 \mathrm{~Hz}), 4.02(1 \mathrm{H}, \mathrm{dd}, J 5.0,4.0 \mathrm{~Hz}), 3.96(1 \mathrm{H}, \mathrm{d}, J 13.8 \mathrm{~Hz}), 3.90$ $(1 \mathrm{H}, \mathrm{d}, \mathrm{J} 13.8 \mathrm{~Hz}), 3.33-3.22(2 \mathrm{H}, \mathrm{m}) ; \delta_{\mathrm{C}}\left(100 \mathrm{MHz}, \mathrm{CDCl}_{3}\right) 173.4,142.8,140.0,137.1,135.5$, $132.6,129.5,129.3,129.2,129.0,128.6,127.7,127.5,122.2,120.0,118.8,118.5,111.5,106.9$, 65.4, 61.4, 56.7, 54.9, 25.0; HRMS (electrospray) $\mathrm{m} / \mathrm{z}$ calc. $[\mathrm{M}+\mathrm{H}]^{+}\left(\mathrm{C}_{28} \mathrm{H}_{27} \mathrm{~N}_{2} \mathrm{O}_{2}\right) 423.2073$, obs. 423.2067.

Allyl (1R,3S)-9-methyl-1-phenyl-2-(phenylmethyl)-2,3,4,9-tetrahydro-1H-pyrido[3,4b]indole-3-carboxylate (16). The allyl ester 15 (571 mg, $1.35 \mathrm{mmol})$ dissolved in dry DMF (15 $\mathrm{ml}$ ) and cooled to $0{ }^{\circ} \mathrm{C}$. $\mathrm{NaH}(54 \mathrm{mg}$ of a $60 \%$ dispersion in mineral oil, $1.35 \mathrm{mmol}$ ) and iodomethane $(92 \mu \mathrm{l}, 1.48 \mathrm{mmol})$ were added and the resultant mixture stirred at $0{ }^{\circ} \mathrm{C}$ for $2 \mathrm{hr}$ and $\mathrm{RT}$ for $2 \mathrm{hr}$. The solvent was removed in vacuo, the residue redissolved in $\mathrm{CH}_{2} \mathrm{Cl}_{2}(15 \mathrm{ml})$ and washed with saturated sodium bicarbonate solution $(30 \mathrm{ml})$. The phases were separated and the aqueous was washed with $\mathrm{CH}_{2} \mathrm{Cl}_{2}(2 \times 15 \mathrm{ml})$. The combined organics were dried over $\mathrm{MgSO}_{4}$, filtered and solvent removed in vacuo. The product was purified by column chromatography using 3:2 $\mathrm{CH}_{2} \mathrm{Cl}_{2}$ : hexane, to give $409 \mathrm{mg}$ (69\%) of a colourless oil. The product $\mathbf{1 6}$ displayed the following ${ }^{1} \mathrm{H}$ NMR data, but was used without further characterisation: $v_{\max } / \mathrm{cm}^{-1}$ (neat) 3057 , $3027,2933,2847,1732,1647,1492,1470,1454,1372,1262,1216,1172,741,700 ; \delta \mathrm{H}(400$ $\left.\mathrm{MHz}_{\mathrm{CDCl}}\right) 7.62(1 \mathrm{H}, \mathrm{d}, J 8.0 \mathrm{~Hz}), 7.41-7.14(13 \mathrm{H}, \mathrm{m}), 5.89(1 \mathrm{H}$, ddt, J 17.2, 10.5, $5.5 \mathrm{~Hz})$, $5.27(1 \mathrm{H}, \mathrm{dq}, J 17.2,1.5 \mathrm{~Hz}), 5.20(1 \mathrm{H}, \mathrm{dq}, J 10.5,1.5 \mathrm{~Hz}), 5.19(1 \mathrm{H}, \mathrm{s}), 4.64(1 \mathrm{H}, \mathrm{ddt}, \mathrm{J} 13.4$, 5.5, $1.5 \mathrm{~Hz}), 4.56$ (1H, ddt, $J$ 13.4, 5.5, $1.5 \mathrm{~Hz}), 3.99(1 \mathrm{H}, \mathrm{d}, J 13.5 \mathrm{~Hz}), 3.96(1 \mathrm{H}, \mathrm{dd}, J$ 7.0, 6.0 $\mathrm{Hz}), 3.79(1 \mathrm{H}, \mathrm{d}, J 13.5 \mathrm{~Hz}), 3.31(3 \mathrm{H}, \mathrm{s}), 3.25(2 \mathrm{H}, \mathrm{dd}, J 9.0,8.0 \mathrm{~Hz}) ; \delta_{\mathrm{C}}\left(100 \mathrm{MHz}, \mathrm{CDCl}_{3}\right)$ 173.2 , 142.0, 140.2, 137.9, 135.4, 132.6, 129.9, 129.4, 128.8, 128.7, 128.1, 127.6, 126.9, 121.7, $119.5,118.8,118.5,109.3,107.5,65.5,59.9,56.5,53.7,30.4,23.5$; HRMS (electrospray) $\mathrm{m} / \mathrm{z}$ calc. $[\mathrm{M}+\mathrm{H}]^{+}\left(\mathrm{C}_{29} \mathrm{H}_{29} \mathrm{~N}_{2} \mathrm{O}_{2}\right) 437.2229$, obs. 437.2219 .

(1R,3S)-9-Methyl-1-phenyl-2-(phenylmethyl)-2,3,4,9-tetrahydro-1H-pyrido[3,4-b]indole-3carboxylic acid (17). The allyl ester 16 (204 mg, $4.7 \mathrm{mmol})$ was dissolved in THF (15 ml) and added via a syringe to $\mathrm{Pd}\left(\mathrm{Ph}_{3}\right)_{4}(53 \mathrm{mg}, 0.47 \mathrm{mmol})$ under Ar. Morpholine $(400 \mu \mathrm{l}, 47 \mathrm{mmol})$ was added via syringe and the resultant mixture was stirred at RT for $10 \mathrm{~min}$. The solvent was removed in vacuo, the residue redissolved in $\mathrm{CH}_{2} \mathrm{Cl}_{2}(15 \mathrm{ml})$ and washed with $2 \mathrm{M} \mathrm{HCl}$ solution 
( $2 \times 15 \mathrm{ml})$. The phases were separated and the aqueous was washed with $\mathrm{CH}_{2} \mathrm{Cl}_{2}(2 \times 15 \mathrm{ml})$. The combined organics were dried over $\mathrm{MgSO}_{4}$, filtered and solvent removed in vacuo. The crude product 17 was used immediately in the following reaction, and displayed: $v_{\max } / \mathrm{cm}^{-1}$ (neat): 3600-2800, 3057, 3031, 2936, 1699, 1471, 1456, 1406, 1311, 1244, 1217, 1189, 1103, 1000, 742, 698.

Ethoxyformic (1R,3S)-9-methyl-1-phenyl-2-(phenylmethyl)-2,3,4,9-tetrahydro-1H-pyrido[3,4-b]indole-3-carboxylic anhydride (18). (1R,3S)-3-Carboxy-1-phenyl-2-phenylmethyl1,2,3,4-tetrahydro-9-methylpyrido[3,4-b]indole was dissolved in $\mathrm{CH}_{2} \mathrm{Cl}_{2}(10 \mathrm{ml})$ and cooled to $10{ }^{\circ} \mathrm{C}$, ethyl chloroformate and $\mathrm{Et}_{3} \mathrm{~N}$ were then added and the resultant solution was stirred at -10 ${ }^{\circ} \mathrm{C}$ for $1 \mathrm{~h}$. The solvent was then removed in vacuo and the crude product $\mathbf{1 8}$ was then used immediately in the next reaction after limited characterisation: $v_{\max } / \mathrm{cm}^{-1}$ (neat): 2931, 2604, $2498,2360,2342,1824,1704,1471,1456,1399,1278,1105,1031,997,741,700 ; \delta_{\mathrm{H}}(400$ $\left.\mathrm{MHz}, \mathrm{CDCl}_{3}\right) 7.76-7.13(14 \mathrm{H}, \mathrm{m}), 5.17(1 \mathrm{H}, \mathrm{s}), 4.28(2 \mathrm{H}, \mathrm{q}, J 7.0 \mathrm{~Hz}), 4.09$ (1H, dd, J 7.0, 6.0 $\mathrm{Hz}), 3.97(1 \mathrm{H}, \mathrm{d}, J 13.5 \mathrm{~Hz}), 3.80(1 \mathrm{H}, \mathrm{d}, J 13.5 \mathrm{~Hz}), 3.35-3.21(2 \mathrm{H}, \mathrm{m}), 3.29(3 \mathrm{H}, \mathrm{s}), 1.34(3 \mathrm{H}$, t, $J 7.0 \mathrm{~Hz})$.

(1R,3S)-3-Diazoacetyl-1-methyl-1-phenyl-2-(phenylmethyl)-2,3,4,9-tetrahydro-1H-pyrido[3,4-b] indole (19). The anhydride 18 was dissolved in $\mathrm{CH}_{2} \mathrm{Cl}_{2}(10 \mathrm{ml})$ and cooled to $-10{ }^{\circ} \mathrm{C}$. An alcohol free ethereal solution of diazomethane $(20 \mathrm{ml})$ was then added via a flame polished pipette and the resultant solution was stirred at $-10{ }^{\circ} \mathrm{C}$ for $1 \mathrm{~h}$ and then RT for $72 \mathrm{~h}$. The solvent was removed under a steady stream of compressed air. The product was purified by column chromatography using $\mathrm{CH}_{2} \mathrm{Cl}_{2}$ as eluent, to give $112 \mathrm{mg}$ (57\% from the allyl ester) of $\mathbf{1 9}$ as a pale yellow oil. The product displayed: $v_{\max } / \mathrm{cm}^{-1}$ (neat): 3031, 2920, 2106, 1742, 1700, 1652, $1471,1395,1343,1314,1282,1212,1185,1106,1031,1006,742,699 ; \delta_{\mathrm{H}}\left(400 \mathrm{MHz}, \mathrm{CDCl}_{3}\right)$ $7.71(1 \mathrm{H}, \mathrm{d}, J 8.0 \mathrm{~Hz}), 7.51-7.20(11 \mathrm{H}, \mathrm{m}), 7.05(2 \mathrm{H}, \mathrm{d}, J 4.0 \mathrm{~Hz}), 5.97(1 \mathrm{H}, \mathrm{s}), 4.95(1 \mathrm{H}, \mathrm{s})$, $3.84(1 \mathrm{H}, \mathrm{d}, J 13.5 \mathrm{~Hz}), 3.78(1 \mathrm{H}, \mathrm{dd}, J 11.0,5.0 \mathrm{~Hz}), 3.64(1 \mathrm{H}, \mathrm{d}, J 13.5 \mathrm{~Hz}), 3.32(3 \mathrm{H}, \mathrm{s}), 3.27-$ $3.06(2 \mathrm{H}, \mathrm{m})$.

HRMS (electrospray) $\mathrm{m} / \mathrm{z}$ calc. [M+H-N $\left.{ }_{2}\right]^{+}\left(\mathrm{C}_{27} \mathrm{H}_{25} \mathrm{~N}_{2} \mathrm{O}\right) 393.1961$, obs. 393.1968.

1-Methyl-1-phenyl-2-(phenylmethyl)-2,3,4,9-tetrahydro-1H-pyrido[3,4-b]indole-3-spiro-(2oxocyclopropane) (22). To a stirred solution of rhodium(II) acetate $(\sim 0.1 \mathrm{mg})$ in $\mathrm{CH}_{2} \mathrm{Cl}_{2}(5 \mathrm{ml})$ under $\mathrm{Ar}$ was added over $2 \mathrm{~h}$ using a syringe pump (1R, 3S)-3-diazoacetyl-1-phenyl-2phenylmethyl-1,2,3,4-tetrahydro-9-methylpyrido[3,4-b]indole (112 mg, $2.67 \mathrm{mmol})$ in $\mathrm{CH}_{2} \mathrm{Cl}_{2}$ $(10 \mathrm{ml})$. The resultant solution was allowed to stir at $\mathrm{RT}$ for $18 \mathrm{hr}$. The solvent was removed in vacuo and the product was purified by column chromatography using $3: 2 \mathrm{CH}_{2} \mathrm{Cl}_{2}$ : hexane as eluent, to give $61 \mathrm{mg}(58 \%)$ of the cyclopropanone 22 as a colourless oil. The product displayed: $v_{\max } / \mathrm{cm}^{-1}$ (neat): 3058, 3028, 2920, 2849, 1805, 1495, 1466, 1455, 1378, 1260, 1169 , 1029,$923 ; \delta_{\mathrm{H}}\left(400 \mathrm{MHz}, \mathrm{CDCl}_{3}\right) 7.45-6.97(14 \mathrm{H}, \mathrm{m}), 4.75(1 \mathrm{H}, \mathrm{s}), 4.12(1 \mathrm{H}, \mathrm{d}, J 13.0 \mathrm{~Hz}), 3.92$ $(1 \mathrm{H}, \mathrm{d}, J 13.0 \mathrm{~Hz}), 3.86(1 \mathrm{H}, \mathrm{d}, J 15.0 \mathrm{~Hz}), 3.76(1 \mathrm{H}, \mathrm{d}, J 15.0 \mathrm{~Hz}), 3.37(1 \mathrm{H}, \mathrm{d}, J 15.0 \mathrm{~Hz}), 3.29$ $(1 \mathrm{H}, \mathrm{d}, J 15.0 \mathrm{~Hz}), 3.24(3 \mathrm{H}, \mathrm{s}) ; \delta_{\mathrm{C}}\left(100 \mathrm{MHz}, \mathrm{CDCl}_{3}\right) 203.4,142.8,141.8,138.7,138.3,129.2$, 129.1, 128.9, 128.8, 127.9, 127.6, 124.2, 121.5, 119.8, 119.4, 109.4, 101.5, 72.1, 54.0, 49.9, 31.3, 31.2; HRMS (electrospray) $\mathrm{m} / \mathrm{z}$ calc. $[\mathrm{M}+\mathrm{H}]^{+}\left(\mathrm{C}_{27} \mathrm{H}_{25} \mathrm{~N}_{2} \mathrm{O}\right) 393.1961$, obs. 393.1968. 


\section{Acknowledgements}

We thank Steve Kelly and Clive Raynor for technical support, and EPSRC for funding.

\section{References and Notes}

1. (a) Present address: Dr Alam Ashnagar, School of Pharmacy, Ahwaz University of Medical Sciences, Ahwaz, Iran. (b) Philip Cochrane: work carried out at Department of Chemistry, Heriot-Watt University, Edinburgh EH14 4AS.

2. (a) Bailey, P. D.; Morgan, K. M. Chem. Commun. 1996, 1479. (b) Bailey, P. D.; Collier, I. D.; Hollinshead, S. P.; Moore, M. H.; Morgan, K. M.; Smith, D. I.; Vernon, J. M. J. Chem. Soc., Perkin Trans. 1 1997, 1209. (c) Bailey, P. D.; Morgan, K. M. J. Chem. Soc., Perkin Trans. 1 2000, 3578. (d) Bailey, P. D.; Cochrane, P. J.; Lorenz, K.; Collier, I. D.; Pearson, D. P. J.; Rosair, G. M. Tetrahedron Lett. 2001, 42, 113. (e) Bailey, P. D.; Clingan, P. D.; Mills, T. J.; Price, R. A.; Pritchard, R. G. Chem. Commun. 2003, 2800.

3. (a) Bailey, P. D.; Hollinshead, S. P. Tetrahedron Lett. 1987, 28, 2879. (b) Bailey, P. D.; Hollinshead, S. P.; McLay, N. R.; Morgan, K. M.; Palmer, S. J.; Prince, S. N.; Reynolds, C. D.; Wood, S. D. J. Chem. Soc., Perkin Trans. 1 1993, 431. (c) Bailey, P. D.; Moore, M. H.; Morgan, K. M.; Smith, D. I.; Vernon, J. M. Tetrahedron Lett. 1994, 35, 3587. (d) Bailey, P. D.; Cochrane, P. J.; Forster, A. H.; Morgan, K. M.; Pearson, D. P. J. Tetrahedron Lett. 1999, 40, 4597. (e) Bailey, P. D.; Morgan, K. M.; Smith, D. I.; Vernon, J. M. J. Chem. Soc., Perkin Trans. 1, 2000, 3566.

4. (a) Schkeryantz, J. M.; Woo, J. C. G.; Danishefsky, S. J. J. Am. Chem. Soc. 1995, 117, 7025. (b)

Cushing, T. D.; Sanz-Cervera, J. F.; Williams, R. M. J. Am. Chem. Soc. 1993, 115, 9323. (c) Szabó-Pusztay, K.; Szabó, L. Synthesis 1979, 276. (d) Ohno, M.; Spande, T. F.; Witkop, B. J. Am. Chem. Soc. 1970, 92, 343.

5. (a) Manucuso, A. J.; Swern, D. Synthesis 1981, 165. (b) Tidwell, T. T. Synthesis 1990, 857.

6. Bailey, P. D.; Cochrane, P. J.; Irvine, F.; Morgan, K. M.; Pearson, D. P. J.; Veal, K. T. Tetrahedron Lett. 1999, 40, 4593.

7. (a) Omura, K.; Sharma, A. K.; Swern, D. J. Org. Chem. 1976, 41, 957. (b) Sharma, A. K.; Ku, T.; Dawson, A. D.; Swern, D. J. Org. Chem. 1975, 40, 2758.

8. Hauser, C. R.; Kantor, S. W.; Brasen, W. R. J. Am. Chem. Soc. 1953, 75, 2660.

9. Manucuso, A. J.; Huang, S.-L.; Swern, D. J. Org. Chem. 1978, 43, 2480.

10. Alberch, L.; Bailey, P. D.; Clingan, P. D.; Mills, T. J.; Price, R. A.; Pritchard, R. G. Eur. J. Org. Chem. 2004, 1887.

11. Ungemach, F.; DiPierro, M.; Weber, R.; Cook, J. M. J. Org. Chem. 1981, 46, 164. 